\title{
Language Policies: Language, Power, and Citizenship
}

\begin{abstract}
Inocência Mata
University of Macau, Macau, China

University of Lisbon, Lisbon, Portugal

This paper, the idea of which first emerged after a roundtable held at the XI CONLAB-CongressoLuso-Afro-Brasileiro de CiênciasSociais (the 11th CONLAB—Luso-Afro-Brazilian Congress of Social Sciences), ${ }^{1}$ on "Diversities and (In)equalities”, aims at raising a reflection about a very topical issue in Africa: the linguistic diversity of African societies. What is at stake here is a reality that, in its ability to promote human development, is usually considered as favoring conflicts of various kinds. What the study proposes to do here therefore, is inquiring into the paradox that arises between the constructional identity of the Portuguese language in Africa (particularly in the three mainland countries which have Portuguese as their official language) and its role as a prime-mover of exclusion, owing to the fact that it continues to be the gatekeeper in relation to other languages (the "home languages"), under the transparent mantle of nation-building and linguistic pacification. All said and done, nothing more has been done than prolonging its colonial role. What language policies (in the plural) should be followed in such a complex setting of language diversity?
\end{abstract}

Keywords: language policies, language diversity, colonial order, citizenship, "home languages”

\section{Introduction}

There seems to be a paradox between the constructional dimension of the Portuguese language in the Five countries where Portuguese is spoken as the statutory language-three mainland countries (Angola, Guinea-Bissau e Mozambique) and two archipelagos (the Cape Verde Islands and the São Tomé and Príncipe Islands), and its role as a prime-mover of exclusion. This is due to the fact that Portuguese continues to be the gatekeeper in relation to other languages (the "home languages") under the transparent mantle of nation-building and linguistic pacification that has, in the end, done nothing more than prolonging its colonial role. What language policies (in the plural) should be followed in such a complex setting for the building of a real citizenship?

Although they display five different realities, the Five are also similar in that they belong to the reality prevailing in Africa. Therefore, by using these five realities as the departure point, the author shall be reflecting upon the circulation and boundaries of language policies in Africa.

Inocência Mata, professor, Ph.D., Department of Portuguese, Faculty of Arts and Humanities, University of Macau; Department of Romance Literatures, Faculty of Letters, University of Lisbon.

1 XI CONLAB-Congresso-Luso-Afro-Brasileiro de Ciências Sociais: Diversidades e (Des)Igualdade held at the Federal University of Bahia-UFBA), Salvador, Brazil, August 7-10, 2011. 


\section{The Place of Linguistic Diversity in Africa}

Everyone has the right, as a client, customer, consumer or user, to receive oral and written information in the language specific to the territory from establishments open to the public.

-Universal Declaration of Linguistic Rights, Article 51, No. 2

The fact has always puzzled the author that linguistic and cultural diversity has been regarded as one of the disadvantages in the African condition while in Europe, it is celebrated as an asset and is considered to be one of the cornerstones of the European project (Maalouf, 2008). This is why, by means of several programs (where the most efficient ones are, in the author's opinion as a university teacher and which is best known, the SOCRATES/ERASMUS Programs), the European Union vigorously defends the building up of plurilingualism and multilingual citizenship. Indeed, although it is quite normal for any African to be plurilinguistic and able to speak more than one language depending upon the place s/he is in and who s/he is talking to, by and large, ${ }^{2}$ multilingualism has not been taken into account by the decision-makers in the post-colonial State's planning of language policy and educational policies. It has not even been deemed worthy of the attention of the think-tanks in terms of development or of some of the scholars ("Africanists", as they like to call themselves) who have espoused the philosophy of developmental pragmatism. Political agents (those in power and their advisors) have withdrawn behind a rhetoric about the inevitability of adopting an official European language that is, more or less spoken mainly by the elite (the cultural and social elite but more recently also by the political and economic elite), which goes precisely against linguistic diversity. The rhetoric is not usually accompanied by any effort to reconvert it from the dominant language (owing to the fact that this language continues to be the language of exclusion). Without a program based on language policy planning, in the long run it will be responsible for placing many of the continent's languages on the back shelf although they will still be the languages of socialization where their use is relegated to the private sphere. In the meantime, in persisting under the symbol of post-modern pragmatism for a long time and in the confusion erupting between progress and assimilation-favoring de-regulation, competitive liberalism and assimilation, ${ }^{3}$ an excuse was given to explain the unequal situation. But today it has become empty discourse upholding the fatal inevitability of the Portuguese language as the "language of national unity" and the country's modernization, championed by a segment of the political and socio-economic elite which had always striven for homogeneity—homogeneity resulting in a linguistic ranking of the county's actual languages.

The language issue is, therefore, one of the thorniest problems in Africa, above all when one thinks about human rights (recall the Universal Declaration of Linguistic Rights, Barcelona, 1996). The fact that the African languages (with very few exceptions) are not made statutory languages or generally speaking, are not being standardized so that not even in the long-term future, may they eventually be used in various spheres of social

\footnotetext{
${ }^{2}$ Some States have tried to implement plurilinguistic policies without, however, achieving any success in overcoming the predominance of English, e.g., National Education Policy Act (Act 27 of 1996) passed in post-Apartheid South Africa—see: http://salanguages.com/education.htm, and also Nigeria—see: Efurosibina E. Adegbija (2004): Multilingualism—A Nigerian Case Study, Trenton, NJ, Africa World Press, Inc..

3 The author understands assimilation in the sense in which it is written in the Universal Declaration of Linguistic Rights: "assimilation, a term which is understood to mean acculturation in the host society, in such a way that the original cultural characteristics are replaced by the references, values and forms of behavior of the host society, must on no account be forced or induced and can only be the result of an entirely free choice" (Article 4, No. 2). This does not mean that the duty of the linguistic group that is "hosted" should be minimized, where this duty calls for upholding an attitude favoring integration into the host community which means encouraging socialization that allows it to share its cultural (and linguistic) characteristics, enabling the overall functioning of society.
} 
life, reveals that not only are they not being promoted as regards their diversity or cultural-linguistic equality, but for this very reason, they are not made into vehicles of empowerment that promote the social upward mobility of their speakers. Apart from this, they help to perpetuate a state of exclusion coming from colonial times. It is within this panorama that Mia Couto's words are also pertinent about the Mozambican case although they may likewise be easily applied to other realities, particularly the Angolan and Guinean scenes (the islands, however, follow a somewhat different rationale although perhaps due more to a difference in degree rather than nature):

During the current century [meaning the 20th century], Portuguese policy in Africa was directed towards fabricating a stratum—composed of "assimilados" [Europeanized Africans]—able to run the colonial machine even after colonialism. Candidates wanting to become "assimilados" had to turn their backs on their religion, give up their culture, cut off their roots. One of the borders between being "civilized” and "uncivilized” involved learning the language of the colonizer. Portuguese colonialism conceded in awarding these black-skinned Portuguese their citizenship in the hope that they would become the reproducers and managers of the colonial system. Thus, today's colonial order was being forged-a colonialism which indigenized, a colonialism that did not need the colonist. (Couto, 2001, p. 349, the author's translation)

The outcome of prolonging the "colonial order"-or because of it-was to give preference to strengthening the Nation-State (which in many instances served to go against the cultural interests of the majority). Furthermore, it bolstered the national building project to the detriment of building up full citizenship owing to the sovereign frailties emerging from international alliances that were more concerned with forming strategic-ideological alliances than with pursuing strategies leading towards the human and social development of their populations.

Indeed, since the independence of the Five African countries speaking Portuguese as their official language, people have heard the constant excuse of "historical inevitability" as regards the status played by the Portuguese language in these countries, or in other words, the access to and feasibility of its status as an official language. So widespread has the question become that in the post-colonial era, it has been subject to other interferences making any approach or reflection about the issue extremely ideological (the various uses of the language and its role in education). At the same time, a promiscuous discourse has crystallized out whereby political, cultural, and pragmatic goals have clashed with class, ethnic or racial interests-sometimes, even involving market interests. Not infrequently in this matter, the result is a reductive manichaeism which has a sterilizing effect owing to underlying surmised or explicit teleological aims. It is not productive to "return" to what can be referred to as having passed, simply because it has no place in this brief reflection. However, it is important to recall what ought to be consensual: If the reasons for political-linguistic philosophy are historical, political, social, administrative and even scientific and diplomatic —in other words, pragmatic — not even in this case may they be considered definitive and irreversible.

It seems that this is what has happened in the last 50 years (or in this particular case, in the last 40 years). Owing to the teleological dimension in studies about Africa such as multilinguism and multiculturality that issue from a heterogeneous reality of the regional and/or national spaces, the cultural analyst (more specifically, the "Africanist”) still considers it to be one of the determining factors behind African under-development. The belief is not always phrased in the most subtle of ways and very often, even reveals arrogant determinism. It is this determinism, backed up by "emergency measures" of a political and socio-economic order, and emphasized by the globalization dynamic, that has prescribed the absence of linguistic policies, fused with inertia as far as developing local languages in their relationship with the statutory language. 


\section{Citizenship and the Role of the "Home Language"}

Most countries of the world use their home languages in their countries in order to make their citizens understand and debate all the nitty-gritty facing their countries effectively.

—Jabulani S. Maphalala

But, if the Portuguese language is really and indubitably taken to be the language of power and, in demarking its geographical territory, it is also an uncontestable feature in the search for identity-national identity—such as in the cases of Angola, Mozambique, and Guinea-Bissau. In recognizing this historical dynamic, one may reach the conclusion - if not unanimous then at least consensual-that the Portuguese language has been the most thoroughly appropriated element on which to found the national unity of those countries-emerging countries where the national project and their place in the world still figure in past and current agendas.

In fact, it would be futile to question the place of the Portuguese language 40 years down the line, if it were not because of the need to learn about the past in order to understand the present: What is undeniable is that not only was Portuguese made a statutory language (thereby becoming the language of power), but it also became a nationalized language or rather, it was naturalized and nativized as a cultural factor (just like any language is), adopted, re-appropriated and re-semantized (and not only by [creative] writers as an aesthetic task). Even if it was first used strictly for utilitarian purposes, in its contact with local African languages, Portuguese has undergone innumerable and diverse changes and has caused other changes in accordance with time-space constraints. African literatures provide the readers with extraordinary examples of this mutual and bilateral transformation process. Moreover, many diglossias have resulted, which linguistic studies and reflections on education in Portuguese as a non-mother tongue have gradually brought into some sort of order and which African literary studies have illustrated.

Nevertheless, although the role of language is important in building identity, one cannot believe that language is the only single-most important factor in the cultural geo-strategy on which human and social development depends. This is because language is, above all, a mass-media phenomenon involving culture and civilization. In other words, it is acceptable that Culture (and by this, Culture roughly means as a set of codes representing experience and ways of interpreting the world) is expressed by means that go beyond the use of language. Within this context, more — or as equally—important than defending the language, it is the defense of culture particularized by language.

Indeed, language embodies the resolutions and contents of its own past as much as its present and future. But language is also a social reality and thus acts as a means of practical communication and by forming subjective awareness. Apart from being one of the basic rights of all human beings (according to the Universal Declaration of Linguistic Rights), using one's "home language" in social dealings is one of the contradictions arising in the era of globalization. The demand to protect minority rights (whether sociological or quantitative) cohabits in a tense relationship with the wish to eradicate specificities and particularities, generally those belonging to the frailer communities that have little or no capacity to voice their demands.

In most of the sub-Saharan African countries there are complex socio-linguistic situations where European languages are made their official languages (the only statutory language in the majority of cases). Nevertheless, social life and communication is done in the one's own language, in autochthonous languages, creoles, or lingua francas. In fact, they are language vehicles even in the urban areas, such as in the case, for example, of 
the Cape-Verdian language, the creole spoken in Guinea-Bissau, Wolof spoken in Dakar (needless to say, Wolof is spoken by $85 \%$ of the Senegalese population apart from having its ethnic roots in a little over $40 \%$ of the people, which makes Senegal one of the most united African countries in socio-linguistic terms), or even Xitsonga spoken by the Shangaan people and Xironga spoken by a large proportion of not only the Mozambicans, but also people in the neighboring states (South Africa, Swaziland, Zimbabwe, and Zambi). ${ }^{4}$ Under such circumstances, relaying messages connected with the vital but at the same time "banal" areas of everyday life- - "banal" in the sense that they should be regarded as basic, elementary routines of life- -has to be done in the languages closest to the people in order to allow for strategies that lead to carrying out education programs for citizenship.

Civic education — that is, training the citizen for community life— has to do with all the matters needed for living in a community: its social, cultural and political life, interactions with the surrounding space, the environment, public health, behavior and interpersonal relationships so that it enhances the harmonious, healthy living and the development of people in all the spaces they move in: urban, periurban, and rural. Moreover, civic education should also take into consideration teaching people about their Constitutional Law, the African Charter of Human and Peoples' Rights, and the Universal Declaration of Human Rights. Civic education should help people to develop their skills as citizens so as to enable them to access sources of information and encourage them to become politically active — which, it is always worth stressing, does not mean the same thing as joining a political party; rather, it means the citizen developing a capacity to protect and up-date moral, ethical and cultural values as well as heritage and material legacies; in other words, it means nurturing the capacity to give their opinions about (and not only judge) what (in)justice is and what attitudes and behaviors are harmful to community life and social cohesion.

In the same way, education for citizenship should seek to improve people's cultural level so as to allow them to handle difficulties and inadequacies and seek solutions in daily life. In order to do this, that is, in order to fulfill such goals, the syllabus based on training citizens and providing them with civic education should include information about community life, topics such sanitary and social education, community hygiene and care (planning where the garbage pits should be, what sound pollution is, information about inoculations, first aid, leisure spots, and recreation). ${ }^{5}$ In accomplishing such goals, information should also be included about managing home life so as to talk about family planning, sex education, aids and drug prevention, the family's active role in school life, social inclusion programs, and handling traditional beliefs and practices (which are often pernicious); finally, information should be given about political rights and civic duties, as well as the rights and duties of the family, and regarding women and children... Enjoying full citizenship means getting to know what the rights and duties of the citizen are, thus making civic education a fundamental means to acquire

\footnotetext{
${ }^{4}$ Information from: Atlas Geográfico, Peoples’ Republic of Mozambique/Ministry of Education, Vol. 1, Stockholm: Esselte Map Service AB, 1986. According to more recent and more reliable sources (2006-http://www.ethnologue.com/country/mz/languages; 1998-Inquérito Nacional aosAgregadosFamiliaressobreCondições de Vida, ResultadosGerais, Instituto Nacional de Estatística, Maputo), there are 2.3 million Xitsonga speakers in Mozambique while Xiranga speakers number approximately 650,000. However, these numbers greatly increase when taking into account the neighboring countries, mainly South Africa, as regards Xitsonga. In terms of the lingua franca therefore, the Makhuwa/Emakhuwa language found in the provinces of Nampula and Cabo Delgado, have an estimated four million speakers, without including the use of Makhuwa by the Koti and the Mwani in Mozambique, and the peoples in southern Malawi.

${ }^{5}$ This text is being reviewed at time when panic has hit the world, although mostly Africa, because of the Ebola epidemic which has finally got the world moving so that it does not become a pandemic. Many of the deaths that occurred at the start of this fatal cycle were due, as everybody knows, to a lack of information about the health precautions needed when treating the infected.
} 
this knowledge.

So as to build citizenship, civic education has to be directed at each and every citizen with the aim of giving her/him information and active training. In order to do so, communication has to be made in the people's own home languages that are used by the community to express their difference and pursue their daily lives in society and at home; languages that they speak actively not only for creating empathy but that also allows them to transmit their everyday utterances more efficiently; where they are able to take in information and express their opinions, and question, discuss and confront Power. This task may be carried out by relying on the institutions and undertaking measures such as literacy campaigns in the mother tongue or home language, and using local radio stations and cultural, social, and civic cooperatives. Such measures should receive Government backing or the support of the institutions and national and international organizations geared to this sort of work. These kinds of initiatives would help people to take a more active role in decision-making that affects their world while allowing them to invest in and valorize their own experience. The South-African historian Jabulani S. Maphalala (2005) has spoken about this matter, saying:

The millions of people of African ancestry at grassroots level who cannot use these languages as effective tools find it extremely difficult to express themselves in their countries of birth and are therefore not empowered. Again, most countries of the world use their home languages in their countries in order to make their citizens understand and debate all the nitty-gritty facing their countries effectively. (p. 366)

This is the panorama that led Cheikh Anta Diop to say one day in Les FondementsCulturels, Techniques et Industriels d'unFuturÉtatFédérald'Afrique Noire (Black Africa: The Economic and Cultural Basis for a Federated State, 1960/1987), that exclusively using the colonizer's language is a way for those in power to sidestep the people's questioning. Although they may be illiterate, people are not devoid of good sense. K. B. Nunn (1997) also wrote in a similar vein:

The suppression of African languages is mainly caused by the fact that the constitutions governing African states ever since their emancipation from colonial rule are based on law which is a Eurocentric enterprise. It is well-known the European law was used in the conquest and enslavement of Africa and other native peoples. (Maphalala, 2005, p. 367)

It is common to hear about cases where programs and projects, designed with the best of intentions, which have failed because they did not take heed of the cultural and psycho-social realities and have not received the endorsement of the very people they were supposed to have benefitted, thus rendering them non-starters for no apparent reason—as if their target populations were inept, ungrateful and very little given to improving their lives. Social democratization should be based on decentralizing plans, actors, strategies, and assessment, and language is absolutely vital in this project which is also concerned with social and human development. This is because democracy means freedom and the capacity to choose, and it may only come about when the citizen possesses knowledge, education and information, and autonomy, which means the capacity to articulate, to communicate, so that the citizen is capable of influencing political Power. Only in this way may the social and national cohesion plan be accomplished in a fair manner. One has to begin with words; that is, using the language may be something good; after all, language is the nationality of thought, so said the Brazilian author politician José Alencar in his reply to the accusation made by the Portuguese writer Pinheiro Chagas (1868), where the latter asserted back in the 19th century, that Brazilian suffered from a "lack of correctness in the Portuguese language, or rather the mania of turning Brazilian into a different language from Old Portuguese owing to foolhardy unwarranted neologisms and grammatical unruliness” (p. 221). Alencar's (1965) reply 
written in stone was: "Language is the nationality of thought, just as the motherland is the nationality of the people” (p. 1).

Therefore, it is also within the context of active citizenship, and not only where protecting cultural identity or mere folklore are concerned, that promoting home languages, mother-tongues spoken by the communities, should be undertaken. Despite the fact that they are (not yet) the languages of learning or the "languages of Power", and here, it is necessary to put it bluntly that the language of Power, such as Russian in the ex-Soviet Union or Servo-Croat in the former Yugoslavia (and here European examples deliberately are given so as to show that language diversity is not inherent to tribalism and is not, therefore, an "under-developed thing”)- people's home languages ought to occupy a predominant place in educating for citizenship. Because active democracy (an expression which should strictly speaking be a obvious redundancy) cannot be achieved without taking into account the means through which citizens take part in democracy, not only because they may not correctly understand the messages (and there are instances of this), but mainly because people have to be given the chance to exercise their right to speak, air their grievances and demand according to their needs and interests. Otherwise, they will be limited to agreeing to and supporting everything, above all if it is delivered in language and terms which are not accessible to them. Because not being conversant in the language in all and every situation, renders them half-women/half-men and therefore, half-citizens. This is why, as Arlindo Barbeitos states in A Sociedade Civil em Angola: Estado, Cidadão, Identidade em Angola (Civil Society in Angola: State, Citizen, identity in Angola, 2003), the State cannot place itself above the rights of individuals and turn them into an instrument to be used in exercising this power, as has happened with some detainers of power bent on privatizing the State, and not only because of questions to do with legacy-making ${ }^{6}$ that is happening in many countries.

In fact, and as many agree, a language develops and is enriched by the use its speakers make of it; languages that are not used tend to disappear owing to the process of transforming them into folklore. The romantic idea that a people may withstand anything is a necessary myth propagated by nationalist discourse but it is fallacious when faced with reality. It is true that languages disappear if measures are not carried out ensuring their preservation. The French linguist Jean Calvet, in his book Linguistique et Colonialisme (1974), refers to the workings of productive forces as a factor leading to linguistic development. He concludes that "each society has the language of its production relations" (Calvet, 1974, p. 39). Thus it is important to esteem the language, grant it full recognition (or rights to the city, to use coin Henri Lefebvre's term) so as to spearhead the work to dignify the language by instating it as useful to society, making it a social asset at school, at church and in governance.

Indeed, to quote the words of Leite de Vasconcelos about the Mirandese language, it is not enough for languages to be the language "do campo, do lar e do amor" ("of the farm, home and love"). On the other hand, if languages are not fixed, they die: The immortality of languages is a myth that universal history has disproved. This is why work done on languages in scientific and cultural studies, as well as in policy-making (not ignoring the legal aspect of these policies) is important. Jabulani S. Maphalala in his above-mentioned article speaks

\footnotetext{
${ }^{6}$ One may transfer this privatization of ownership that involves removing an asset from the public domain and hitherto available to everyone, with the case of making the statutory (European) language the sole vehicle of formal communication: It is like privatizing it and robbing people who have no claim to it, of their birthright, of their right to the ownership of their own home languages, of what is theirs. It is curtailing their right to democracy. Thus language ownership, and particularly the languages that have subsequently been marginalized by the elite, spells empowerment which could be a problem for some kinds of [political] systems.
} 
about this when talking about the future of African languages. He states: "African languages are facing extinction unless African governments on the African continent pass legislations which will oblige all people of African ancestry and any foreigner living in Africa to use them in education, commerce and government” (Maphalala, 2005, p. 363).

\section{Conclusion}

The point here is the need for preserving the linguistic diversity of African countries and how it is a way of promoting human development. It is not the author's intention in this firm defense of respecting the difference, in defense of linguistic heterogeneity, to argue for extreme relativism and espouse hypercritical multilingualism. It would make things very difficult in countries facing shortages in human and material resources. What needs to be done is to conciliate "the dialectic of the multiple and of the single, of the diversities of cultures and democracy” (Wieviorka, 2002, p. 119). What the author wanted to do is to call attention to the need to lay the groundwork leading to feasible policy-making, even at long-term, that respects and promotes plurality, whether it is cultural or linguistic, or whether it is political or ideological (although this latter point has not been considered here). After all, plurality is a fundamental principle in democratic life and social harmony.

\section{References}

Adegbija, E. E. (2004). Multilingualism-A Nigerian case study. Trenton, NJ: Africa World Press, Inc..

Alencar, J. de. (1965). Pós-Escrito (Post-script). In Diva (pp. 399-400). Rio de Janeiro: Aguilar.

Barbeitos, A. (2003). A Sociedade Civil em Angola: Estado, Cidadão, Identidade em Angola (Civil society in Angola: The state, the citizen and identity in Angola). Lisboa: Edições Imbondeiro.

Calvet, J. (1974). Linguistique et Colonialisme (Linguistics and colonialism). Paris: Payot.

Chagas, P. (1868). Literatura brasileira (Brazilian literature). In Novos Ensaios Críticos (New critical essays) (pp. 212-224). Porto: Viúva Moré.

Couto, M. (2001). Lusofonia—história ou conveniência? (Lusphony—History or convenience?). Litterata—Revista do Centro de Estudos Portugueses Hélio Simões, 2, 347-355.

Diop, C. A. (1960/1987). Black Africa: The economic and cultural basis for a federated state. Chicago: Lawrence Hill Books.

Maalouf, A. (2008). Multilinguism: An asset for Europe and a shared commitment. Communication from the Commission to the European Parliament, the Council, the European Economic and Social Committee and the Committee of the Regions, Brussels.

Maphalala, J. S. (2005). African languages: Obstacles to internationalism or additional wealth for the world? In I. Mandé \& B. Stefanson (Eds.), LesHistoriens Africaines et la Mondalisation (African historians and globalization) (pp. 363-378). Bamako: AHA/Paris: Karthala.

Peoples' Republic of Mozambique/Ministry of Education. (1986). Atlas Geográfico (Geography Altas) (Vol. 1). Stockholm: Esselte Map Service AB.

UNESCO. (1996). Universal declaration on linguistic rights. Retrieved from http://www.unesco.org/cpp/uk/declarations/ linguistic.pdf

Wieviorka, M. (2002). A Diferença (The difference). Lisboa: Fenda. 